\title{
THE RELATIONSHIP BETWEEN ARM MUSCLE STRENGTH, LEG MUSCLE STRENGTH, ARM POWER AND LEG POWER ON THE 25 METER CRAWL STYLE SWIMMING ACHIEVEMENT
}

\author{
Ardhika Falaahudin $^{1 *}$, Dody Tri Iwandana ${ }^{1}$, Wildan Alfia Nugroho ${ }^{2}$, Cerika Rismayanthi ${ }^{3}$ \\ ${ }^{1}$ Program Studi Ilmu Keolahragaan, Fakultas Keguruan dan Ilmu Pendidikan, Universitas Mercu Buana \\ Yogyakarta, Jl. Raya Wates-Jogjakarta Argomulyo, Kec. Sedayu, Kab. Bantul, Daerah Istimewa \\ Yogyakarta, Indonesia \\ ${ }^{2}$ Program Studi Pendidikan Guru Sekolah Dasar Pendidikan Jasmani, Fakultas Pendidikan Olahraga dan \\ Kesehatan, Universitas Pendidikan Indonesia, J1. Dr. Setiabudhi No.229 Isola, Kec. Sukasari, Kota Bandung, \\ Jawa Barat, Indonesia \\ ${ }^{3}$ Program Studi Ilmu Keolahragaan, Fakultas Ilmu Keolahragaan, Universitas Negeri Yogyakarta, Jl. \\ Colombo Yogyakarta No.1 Karang Malang, Caturtunggal, Kec. Depok, Kab. Sleman, Daerah Istimewa \\ Yogyakarta, Indonesia \\ ardhika@mercubuana-yogya.ac.id,dodytriiwandana@mercubuana-yogya.ac.id, wildanalfian@upi.edu, \\ cerikafik@gmail.com
}

\begin{abstract}
This study aims to determine the relationship between arm muscle strength, leg muscle strength, arm power and leg power on the 25 meter crawl style swimming achievement. This research is a correlational research. The subjects of this study were all members of the swimming club Tirta Serayu Banjarnegara totaling 11 respondents. Data collection techniques using surveys. Data collection techniques using tests and measurements. The instruments used in this study were Hand grip dynamometer, Leg and Back dynamometer, modified spring scales, vertical jump, and 25 meter crawl style swimming. The data analysis technique used regression and correlation analysis, through the prerequisite test for normality and linearity. From the results of the study it can be concluded that there is a significant relationship between arm muscle strength and 25 meter crawl style swimming achievement, there is no significant relationship between leg muscle strength and 25 meter crawl style swimming achievement, there is a significant relationship between arm power and crawl style swimming achievement. 25 meters, there is no significant relationship between leg power and 25 meter crawl style swimming achievement. Overall, there is no significant relationship between arm muscle strength, leg muscle strength, arm power and leg power on the 25 meter crawl swimming achievement.
\end{abstract}

Keywords: Achievement; Swimming; Crawl Style

\section{HUBUNGAN KEKUATAN OTOT LENGAN, OTOT TUNGKAI, POWER LENGAN DAN POWER TUNGKAI TERHADAP PRESTASI RENANG GAYA CRAWL 25 METER}

\begin{abstract}
Abstrak
Penelitian ini bertujuan untuk mengetahui hubungan antar kekuatan otot lengan, kekuatan otot tungkai, power lengan dan power tungkai terhadap prestasi renang gaya crawl 25 meter. Penelitian ini merupakan penelitian korelasional. Subyek dari penelitian ini adalah seluruh anggota klub renang Tirta Serayu Banjarnegara yang berjumlah 11 responden. Teknik pengumpulan data menggunakan survey. Teknik pengambilan data menggunakan tes dan pengukuran. Instrumen yang digunakan dalam penelitian ini berupa hand grip dynamometer, leg and back dynamometer, timbangan pegas modifikasi, vertical jump, dan renang gaya crawl 25 meter. Teknik analisis data menggunakan analisis
\end{abstract}


regresi dan korelasi, melalui uji prasyarat normalitas dan linearitas. Dari hasil penelitian bisa disimpulkan bahwa ada hubungan yang signifikan antara kekuatan otot lengan dengan prestasi renang gaya crawl 25 meter, tidak ada hubungan yang signifikan antara kekuatan otot tungkai dengan prestasi renang gaya crawl 25 meter, ada hubungan yang signifikan power lengan dengan prestasi renang gaya crawl 25 meter, tidak ada hubungan yang signifikan antara power tungkai dengan prestasi renang gaya crawl 25 meter. Secara keseluruhan tidak ada hubungan yang signifikan antara kekuatan otot lengan, kekuatan otot tungkai, power lengan dan power tungkai terhadap prestasi renang gaya crawl 25 meter.

Kata kunci: Prestasi, Renang, Gaya Crawl

\section{PENDAHULUAN}

Olahraga merupakan kebutuhan setiap manusia di dalam kehidupan, agar kondisi fisik dan kesehatannya dapat tetap terjaga dengan baik (Prasetyo, 2015). Kebutuhan akan olahraga sudah menjadi bagian dari gaya hidup, baik untuk olahraga yang bersifat rekreasional, permainan, dan prestasi (Oktadinata et al., 2017). Olahraga mempunyai sifat yang menyenangkan dan universal. Artinya, olahraga dapat dilakukan oleh semua kalangan usia tanpa terkecuali. Salah satu olahraga yang direkomendasikan untuk semua kalangan usia adalah olahraga renang (Susanto, 2015).

Renang merupakan olahraga yang dilakukan di air yang bisa dilakukan baik laki-laki maupun perempuan di segala kalangan usia (Wahyudi, 2015). Renang merupakan olahraga yang mempunyai banyak manfaat dan minim terjadi cedera, karenanya renang dianggap aman dilakukan bagi semua kalangan usia. Renang juga digunakan beberapa orang untuk meningkatkan level percaya diri, rekreasi, terapi, hingga pencapaian prestasi (Firdausi, 2018). Dalam hal prestasi, renang merupakan salah satu olahraga yang sering dipertandingkan baik di tingkat lokal sampai dengan internasional (Paramita et al., 2020). Karakteristik olahraga renang yang melibatkan seluruh bagian tubuh untuk tetap aktif bergerak di air dan juga berat tubuh yang mengalami resistensi oleh air sehingga sangat cocok untuk menjaga kesegaran dan kebugaran tubuh (Palar et al., 2015). Selain untuk menjaga kesehatan, olahraga renang juga dapat meningkatkan kebugaran. Kebugaran badan merupakan hal yang penting untuk dapat melakukan berbagai aktivitas tanpa mengalami kelelahan yang berarti.

Dalam konteks olahraga prestasi, renang membutuhkan waktu tercepat agar seorang atlet dapat menjadi pemenang perlombaan (Surahman, 2016). Beberapa faktor yang mempengaruhi kecepatan sehingga mendapatkan waktu yang tercepat yaitu diantaranya teknik start, turn, finish, daya tahan, power, kecepatan, dan mental (Sukmawati \& Hartoto, 2015). Program latihan yang tepat sangat perlu diberikan agar peningkatan prestasi seorang perenang dapat tercapai dengan maksimal (Susanto, 2017). Selain itu program latihan yang mencakup aspek fisik dan teknik ditambah dengan pengaturan gizi yang tepat juga perlu diperhatikan. Pada periode persiapan, periode pertandingan maupun periode pemulihan di pemusatan latihan, asupan makanan atau gizi atlet juga harus diatur sedemikian rupa sehingga mampu mendukung dalam peningkatan kondisi fisik atlet (Setiawan et al., 2017). Seorang atlet yang mengkonsumsi makanan dengan gizi seimbang dan secara terencana akan berada pada status gizi baik (Baja \& Rismayanthi, 2019). Status gizi yang baik akan mampu mendukung dan mempertahankan kondisi fisik menjadi lebih prima (Rismayanthi, 2015). Pemberian asupan gizi yang tepat akan memberikan sumbangan energi yang lebih baik bagi tubuh yang dapat meningkatkan kinerja fisik pada saat berenang.

Terdapat empat gaya yang diperlombakan dalam renang yaitu gaya bebas ( $\mathrm{crawl})$, gaya kupu - kupu (butterfly), gaya dada (breaststroke) dan gaya punggung (backstroke) (Rohman, 2019). Dalam renang prestasi, aturan (rule) mengacu pada peraturan induk organisasi olahraga yang bersangkutan. Di Indonesia, induk olahraga renang adalah Persatuan Renang Seluruh Indonesia, disingkat PRSI. Dikutip dari situs resmi PRSI, Persatuan Renang Seluruh Indonesia adalah organisasi yang mengatur olahraga renang di Indonesia. Sementara untuk di level international, Federasi Renang Internasional (Fédération Internationale de Natation, 
disingkat FINA) adalah induk organisasi internasional olahraga renang. Organisasi ini diakui oleh Komite Olimpiade Internasional (IOC). FINA berpusat di kota Lausanne, Swiss. Selain mengadakan kejuaraan internasional dan regional, tugas FINA juga selalu berusaha memajukan olahraga renang di seluruh dunia antara lain dengan menambah jumlah fasilitas olahraga renang. FINA juga bertugas membuat peraturan internasional untuk kejuaraan renang, renang perairan terbuka, selam, polo air, dan renang indah.

Beberapa unsur yang ditonjolkan pada renang prestasi adalah unsur kecepatan (Speed), daya tahan (endurance). Smentara gaya dan teknik gerakan yang benar juga sangat diperhatikan (Sungkowo, Kaswarganti Rahayu, 2015). Gaya bebas adalah gaya berenang dengan posisi dada meghadap ke air dan kepala kepala berada di dalam air. Posisi badan lurus, kaki turun naik akan tetapi tidak menekuk melainkan dengan posisi kaki lurus. Tangan mengayuh kedepan bergantian dan mengambil nafas dengan menoleh ke arah kanan atau kiri dengan posisi muka keluar dari permukaan air (Rizkiyansyah \& Mulyana, 2019). Terdapat bebrapa indikator kunci pada gaya bebas ( $\mathrm{crawl}$ ) yang harus diperhatikan yaitu (1). Sikap tubuh (2). Gerakan kaki (3). Gerakan lengan (4). Bernafas dan koordinasi gerak.

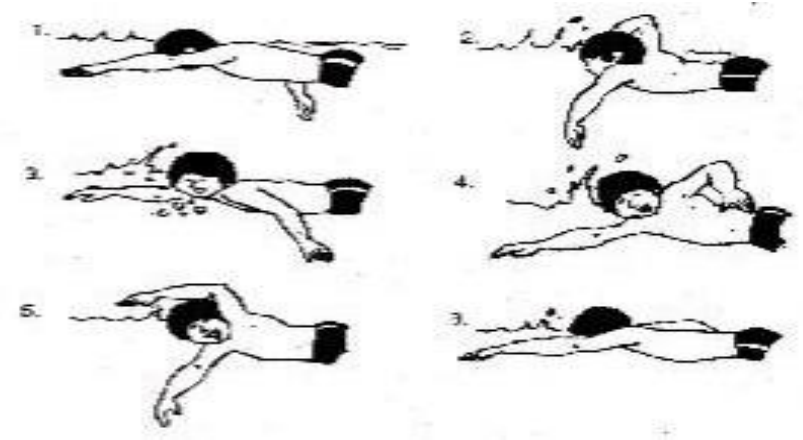

Gambar 1. Gerakan Gaya Bebas (Crawl) Sumber : (Rahima, Ahmad Atiq, 2013)

1) Posisi tubuh datar, sedikit menyamping dari bagian pinggang kebawah. 2) Pendangan mata kedepan dan sedikit kebawah. 3) Posisi badan yang agak serong memudahkan tendangan ketika didalam air. 4) Sumber kayuhan lengan berasal dari bahu, manfaatkan otot-otot dada yang kuat dan memberi suatu dorongan yang kuat. 5) Posisi tubuh dapat menyebabkan kayuhan kaki.

Kekuatan otot dalam olahraga renang mempunyai peranan yang penting (Muliarta, 2015). Kekuatan otot dalam hal ini kekutan otot lengan, otot tungkai. Tidak hanya kekuatan otot, power lengan dan power tungkai secara bersama berperan penting dalam menghasilkan gerakan maju dalam berenang (Wicaksono, 2017). Otot lengan, otot tungkai, power lengan dan power tungkai masing-masing memberikan sumbangan pada gerakan maju saat berenang (Putra \& Witarsyah, 2019). Berkaitan dengan hal ini muncul pertanyaan seberapa berapa besar sumbangan masing-masing kekuatan otot lengan, otot tungkai, power lengan dan power tungkai dalam memberikan sumbangan yang signifikan terhadap kecepatan renang gaya crawl 25 meter. Penelitian akan menjawab pertanyaan dan membahas serta menjabarkan dengan rinci tentang seberapa besar sumbangan dari masing-masing faktor tersebut.

Perkumpulan renang merupakan wadah pembinaan yang paling mendasar untuk menjalankan aktivitas latihan mulai dari tahap paling bawah, hingga mencapai tahap pembinaan yang paling atas yaitu pencapaian prestasi optimal atlet. Kaitannya dengan olahraga renang gaya crawl ternyata di Klub renang Tirta Serayu Banjarnegara memiliki prestasi yang tinggi. Hal ini tampak terlihat pada saat mengikuti Kejuaraan Renang Antar Perkumpulan (KRAP) di tingkat provinsi Jawa Tengah mendapatkan peringkat 6 dari 34 peserta dengan perolehan medali 9 emas, 3 perak dan 4 perunggu (Falaahudin \& Sugiyanto, 
2013).

Berkaitan dengan renang gaya crawl 25 meter belum diketahui hubungan kekuatan otot lengan, otot tungkai, power lengan, power tungkai dan seberapa besar sumbangannya terhadap prestasi siswa renang di Tirta Serayu Banjarnegara. Dari keterkaitan dua hal tersebut mengenai kekuatan otot lengan dan kekuatan otot tungkai pada atlet Klub renang Tirta Serayu Banjarnegara. Perlu diketahui hubungan dan seberapa besar sumbangannya, hal ini menjadi penting dalam rangka mencari panduan untuk meningkatkan prestasi olahraga renang gaya crawl. Penggunaan jarak 25 meter yang bukan merupakan nomor perlombaan ditujukan agar dalam pengambilan data, sampel penelitian dapat melakukan semaksimal mungkin atau sprint. Harapannya, dengan melakukannya secara maksimal akan memperjelas hubungan dan sumbangan dari bebrapa variable yang diteliti tersebut. Dari uraian pemikiran di atas maka peneliti berkeinginan untuk mengkaji hubungan antara kekuatan otot lengan dan kekuatan otot tungkai terhadap kecepatan renang gaya crawl pada atlet klub Tirta Serayu Banjarnegara.

\section{METODE}

Populasi dalam penelitian ini adalah seluruh atlet klub Tirta Serayu Banjarnegara yang berjumlah 11 orang. Teknik pengumpulan data dalam penelitian ini dengan menggunakan beberapa tes yaitu tes otot lengan menggunakan hand grip dynamometer, tes otot tungkai dengan leg and back dynamometer, power otot tungkai diukur dengan vertical power jump test, power otot lengan dilakukan dengan menggunakan neraca pegas, dan tes untuk melakukan renang gaya crawl dengan jarak 25 meter. Tes renang gaya crawl ini diulang sebanyak tiga kali. Teknik pengumpulan data yang digunakan dalam penelitian ini menggunakan metode survey yaitu dengan teknik tes dan pengukuran.

Dalam penelitian ini teknik analisis data yang digunakan adalah uji validitas, uji linearitas, uji normalitas, uji homogenitas, dan uji korelasi. Pada penelitian ini untuk mengetahui validitas instrument tes menggunakan validitas logis. Validitas logis karena validitas ini diperoleh dengan suatu usaha hati-hati melalui cara-cara yang benar sehingga menurut logika akan dicapai suatu tingkat validitas yang dikehendaki. Karena menggunakan valisitas logika maka tidak perlu menggunakan perhitungan statistika.

Uji linearitas digunakan untuk mengetahui sifat hubungan linear atau tidaknya antara variabel bebas dengan variabel terikat. Untuk keperluan uji linearitas dengan uji $\mathrm{F}$. Selanjutnya nilai $\mathrm{F}$ dikonsultasikan dengan nilai tabel pada taraf signifikansi 5\%. Dikarenakan linier apabila harga $\mathrm{F}$ observasi lebih kecil dari $\mathrm{F}$ tabel dan sebaliknya. Uji normalitas data dimaksudkan untuk mengetahui apakah sebaran masing-masing variabel bebas maupun terikat mempunyai distribusi normal atau tidak. Uji normalitas dalam penelitian ini menggunakan rumus Chi Kwadrat. Uji korelasi digunakan untuk mengetahui hubungan antara masingmasing variabel bebas terhadap variabel terikat menggunakan rumusan person product moment.

Untuk menguji apakah nilai $\mathrm{R}$ tersebut signifikan atau tidak dilakukan uji $\mathrm{F}$ dengan kemudian di konsultasikan dengan nilai $\mathrm{F}$ tabel dengan derajat kebebasan $\mathrm{N}-\mathrm{m}-1$ pada taraf signifikansi 5\%. Apabila nilai $\mathrm{F}$ hitung lebih besar atau sama dengan nilai $\mathrm{F}$ tabel, maka ada hubungan yang signifikan antara variabel terikat dengan masing - masing variabel bebasnya.

\section{HASIL DAN PEMBAHASAN}

\section{Uji Prasyarat}

Uji normalitas menggunakan Chi Kuadrat. Hasil uji normalitas menunjukkan bahwa harga $X^{2}$ hitung dari variabel kekuatan otot lengan sebesar 1,273, variabel kekuatan otot tungkai sebesar 0,818, variabel power lengan sebesar 2,636, variabel power tungkai sebesar 1,091 , dan variabel prestasi renang gaya crawl sebesar 0,000 . nilai $X^{2}$ hitung kelima variabel

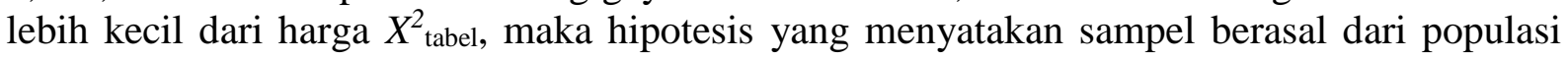


MEDIKORA, Vol. 20 No. 1 April 2021 - 97

Ardhika Falaahudin, Dody Tri Iwandana, Wildan Alfia Nugroho, Cerika Rismayanthi

berdistribusi normal diterima. Dengan demikian dapat disimpulkan bahwa kenormalan berdistribusi terpenuhi.

Tabel 1. Hasil Uji Linearitas

\begin{tabular}{lllll}
\hline Persamaan Regresi & F & df & Ft & Simpulan \\
\hline $\mathrm{Y}=20,093+0,599 \mathrm{X}_{1}$ & 0,195 & $7 / 2$ & 19,353 & Linear \\
$\mathrm{Y}=39,765+0,265 \mathrm{X}_{2}$ & 0,753 & $8 / 1$ & 283,883 & Linear \\
$\mathrm{Y}=11,683+0,767 \mathrm{X}_{3}$ & 0,433 & $4 / 5$ & 5,192 & Linear \\
$\mathrm{Y}=32,579+0,349 \mathrm{X}_{4}$ & 1,037 & $5 / 4$ & 6,254 & Linear \\
\hline
\end{tabular}

Hasil perhitungan uji linearitas diperoleh harga $\mathrm{F}$ hitung lebih besar dari $\mathrm{F}$ tabel, maka hipotesis yang menyatakan garis regresi berbentuk linear diterima.

2. Analisis Data

Hasil dari perhitungan korelasi sederhana antara kekuatan otot lengan (X1) dengan prestasi renang gaya crawl (Y) sebesar 0,559, kekuatan otot tumgkai (X2) dengan prestasi renang gaya crawl (Y) sebesar 0,205, power lengan (X3) dengan prestasi renang gaya crawl (Y) sebesar 0,766, dan power tungkai (X4) dengan prestasi renang gaya crawl (Y) sebesar 0,349 .

Tabel 2. Hasil Uji Multikolinearitas

\begin{tabular}{ccccc}
\hline & B & Korelasi Parsial & VIF & Simpulan \\
\hline Konstanta & 11,883 & & & Tidak terjadi Multi kolinearitas \\
X1 & 0,073 & 0,075 & 2,336 & \\
X2 & 0,041 & 0,060 & 1,154 & \\
X3 & 0,766 & 0,606 & 2,509 & \\
X4 & $-0,118$ & $-0,148$ & 1,549 & \\
\hline
\end{tabular}

Dari perhitungan uji multikolinearitas nilai VIF semuanya terletak diantara 0-10, maka dapat disimpulkan tidak terjadi multikolinearitas.

Tabel 3. Koefisien Korelasi Ganda

\begin{tabular}{lcl}
\hline Hubungan antar Variabel & Persamaan Garis regresi & Koefisien Korelasi \\
\hline $\mathrm{X}_{1}, \mathrm{X}_{2}, \mathrm{X}_{3}, \mathrm{X}_{4}, \mathrm{Y}$ & $\mathrm{Y}=11,883+0,073 \mathrm{X}_{1}+$ & 0,773 \\
& $0,041 \mathrm{X}_{2}+0,776 \mathrm{X}_{3}-$ & \\
& $0,118 \mathrm{X}_{4}$ & \\
\hline
\end{tabular}

Untuk hasil korelasi ganda diperoleh koefisien korelasi ganda antara otot lengan, kekuatan otot tungkai, power lengan dan power tungkai sebesar 0,773.

3. Uji Hipotesis

a. Hipotesis Pertama

Tabel 4. Hasil Uji Hubungan Sederhana X1Y

\begin{tabular}{llllll}
\hline Korelasi & $\mathbf{r}$ & $\mathbf{t}_{\mathbf{0}}$ & $\mathbf{d f}$ & $\mathbf{t}_{\mathbf{t}}$ & \\
\hline $\mathrm{X} 1 \mathrm{Y}$ & 0,559 & 2,242 & 10 & 1,812 & Signifikan \\
\hline
\end{tabular}

Hasil uji hubungan sederhana diperoleh harga $t$ perhitungan hubungan sederhana antara kekuatan otot lengan dengan prestasi renang gaya crawl 25 meter sebesar 
Ardhika Falaahudin, Dody Tri Iwandana, Wildan Alfia Nugroho, Cerika Rismayanthi

2,242 dengan $\mathrm{t}$ tabel sebesar 1,812. Dengan demikian dapat ditarik kesimpulan bahwa ada hubungan signifikan antara kekuatan otot lengan dengan prestasi renang gaya crawl 25 meter.

b. Hipotesis Kedua

Tabel 5. Hasil Uji Hubungan Sederhana X1Y

\begin{tabular}{llllll}
\hline Korelasi & $\mathbf{r}$ & $\mathbf{t}_{\mathbf{o}}$ & $\mathbf{d f}$ & $\mathbf{t}_{\mathbf{t}}$ & \\
\hline $\mathrm{X} 2 \mathrm{Y}$ & 0,205 & 0,629 & 10 & 1,812 & Tdk Signifikan \\
\hline
\end{tabular}

Hasil uji hubungan diperoleh harga $\mathrm{t}$ perhitungan hubungan sederhana antara kekuatan otot tungkai dengan prestasi renang gaya crawl 25 meter sebesar 0,629 dan t tabel sebesar 1,1812. Dengan demikian dapat ditarik kesimpulan bahwa tidak ada hubungan yang signifikan kekuatan otot tungkai dengan prestasi renang gaya $\mathrm{crawl}$ 25 meter.

c. Hipotesis ketiga

Tabel 6. Hasil Uji Hubungan Sederhana X1Y

\begin{tabular}{llllll}
\hline Korelasi & $\mathbf{r}$ & $\mathbf{t}_{\mathbf{o}}$ & $\mathbf{d f}$ & $\mathbf{t}_{\mathbf{t}}$ & \\
\hline $\mathrm{X} 3 \mathrm{Y}$ & 0,766 & 3,572 & 10 & 1,812 & Signifikan \\
\hline
\end{tabular}

Hasil uji hubungan sederhana diperoleh t perhitungan hubungan sederhana antara power lengan dengan prestasi renang gaya crawl 25 meter sebesar 3,572 dan t tabel sebesar 1,812. Dengan demikian dapat ditarik kesimpulan bahwa ada hubungan yang signifikan antara power lengan dengan prestasi renang gaya crawl 25 meter.

d. Hipotesis Keempat

Tabel 7. Hasil Uji Hubungan Sederhana X1Y

\begin{tabular}{llllll}
\hline Korelasi & $\mathbf{r}$ & $\mathbf{t}_{\mathbf{o}}$ & $\mathbf{d f}$ & $\mathbf{t}_{\mathbf{t}}$ & \\
\hline $\mathrm{X} 4 \mathrm{Y}$ & 0,349 & 1,117 & 10 & 1,812 & Tdk Signifikan \\
\hline
\end{tabular}

Hasil uji hubungan sederhana diperoleh harga t perhitungan hubungan sederhana antara power tungkai dengan prestasi renang gaya crawl 25 meter sebear 1,117 dan t tabel sebesar 1,812. Dengan demikian dapat ditarik kesimpulan bahwa tidak ada hubungan yang signifikan antara power tungkai dengan prestasi renang gaya crawl 25 meter.

e. Hipotesis Kelima

Tabel 8. Hasil Uji Hubungan Sederhana X1Y

\begin{tabular}{llll}
\hline Korelasi ganda & $\mathbf{F}_{\mathbf{0}}$ & $\mathbf{F}_{\mathbf{t}}$ & \\
\hline $\mathrm{X}_{1} \mathrm{X}_{2} \mathrm{X}_{3} \mathrm{X} 4 \mathrm{Y}$ & 2,224 & 4,534 & Tdk signifikan \\
\hline
\end{tabular}

Hasil uji hubungan secara keseluruhan diperoleh harga $\mathrm{F}$ hitung secara bersamasamaantara kekuatan otot lengan, kekuatan otot tungkai, power lengan, dan power tungkai dengan prestasi renang gaya crawl 25 meter sebesar 2,224. Karena F hitung lebih besar dari $\mathrm{F}$ tabel ( $\mathrm{F}$ hitung $<\mathrm{F}$ tabel 4,534) maka dapat ditarik kesimpulan bahwa secara bersama-sama tidak ada hubungan yang signifikan antara kekuatan otot lengan, kekuatan otot tungkai, power lengan, dan power tungkai dengan prestasi 
MEDIKORA, Vol. 20 No. 1 April 2021 - 99

Ardhika Falaahudin, Dody Tri Iwandana, Wildan Alfia Nugroho, Cerika Rismayanthi

renang gaya $\mathrm{crawl} 25$ meter.

4. Interkorelasi

Tabel 9. Matriks Korelasi Sederhana

\begin{tabular}{llllll}
\hline Var & $\mathbf{X 1}$ & $\mathbf{X 2}$ & $\mathbf{X 3}$ & $\mathbf{X 4}$ & $\mathbf{Y}$ \\
\hline $\mathbf{X 1}$ & 1 & 0,266 & 0,747 & 0,488 & 0,599 \\
$\mathbf{X 2}$ & 0,266 & 1 & 0,242 & 0,348 & 0,205 \\
$\mathbf{X 3}$ & 0,747 & 0,242 & 1 & 0,545 & 0,766 \\
$\mathbf{X 4}$ & 0,488 & 0,348 & 0,545 & 1 & 0,349 \\
$\mathbf{Y}$ & 0,599 & 0,205 & 0,766 & 0,349 & 1 \\
\hline
\end{tabular}

Berdasarkan tabel diatas diketahui bahwa terdapat beberapa hubungan antara variabel bebas dengan variabel bebas lainnya daripada variabel bebas dengan variabel terikat. Hubungan antara kedua otot lengan dengan power lengan sangat kuat, yaitu sebesar 0,747, hubungan kekuatan otot tungkai dengan power tungkai juga lebih besar daripada hubungan kekuatan otot tungkai dengan prestasi renang, yaitu sebesar 0,348. Hubungan power lengan dengan power tungkai juga besar yaitu 0,545 yang lebih besar dari pada hubungan power tungkai dengan prestasi renang. Beberapa variabel bebas mempunyai hubungan yang kuat dengan variabel bebas lainnya. Karena hubungan kekuatan otot tungkai dan power tungkai dengan prestasi renang gaya crawl 25 meter tidak signifikan, menyebabkan hubungan secara bersama-sama dari keempat variabel bebas terhadap variabel terikat juga tidak signifikan.

Menurut (Evenetus et al., 2019) peningkatan kecepatan renang dapat juga dipengaruhi oleh kualitas otot yang dimiliki perenang. Selain otot lengan, untuk memperoleh hasil kecepatan renang yang maksimal, tentunya diperlukan juga sumbangan dari bebrapa kelompok otot sinergis yang mendukung gerakandalam berenang sehingga kecepatan renang dapat meningkat. Dari sekian banyak kelompok otot yang terdapat di tubuh, otot yang berperan dalam gerakan renang yang paling dominan yaitu otot lengan, bahu, perut dan tungkai. Kekuatan kelompok otot-otot tersebut terbukti memeliki peran yang signifikan dalam meningkatkan kecepatan renang.

Untuk mendapatkan kondisi fisik yang baik, tentu saja tidak terlepas dari pemberian metode-metode latihan yang sistematis dan terukur. Pemberian metode latihan yang sesuai, takaran latihan yang sesuai, serta asupan gizi yang tepat akan mengoptimalkan prestasi pada atlet. Salah satu faktor yang mempengaruhi meningkatnya prestasi dan keterampilan seorang atlet adalah latihan yang dilakukan secara berulang-ulang. Latihan berulang-ulang dimaksudkan agar atlet semakin baik dalam penguasaan teknik gerakan sehingga akan terjadi gerakan yang efisian dan semakin lama akan menjadi otomatisasi gerak. Penambahan beban dan intensitas juga dilakukan dalam program latihan seorang perenang. Dengan menambahjumlah beban latihan serta intensitas latihannya secara berkala dan terukur. Selain untuk meningkatkan kualitas fisik dan teknik, tujuan latihan juga untuk membantu atlet meningkatkan kualitas psikologis untuk meningkatkan kinerja mereka pada saat kompetisi atau berlomba (Surahman, 2016).

Dari hasil penelitian diperoleh nilai korelasi antara kekuatan otot lengan dengan prestasi renang gaya crawl 25 meter cukup besar, yaitu 0,599. Berdasarkan pengujian hipotesis hubungan keduanya signifikan. Dalam renang gaya $\mathrm{crawl}$, kekuatan otot lengan dibutuhkan untuk menarik air pada saat gerakan tangan menarik dari depan hingga ke bawah perut. Semakin besar kekuatan otot lengan seseorang, semakin besar tarikan yang dihasilkan, sehingga laju renang ke depan juga semakin cepat. Nilai korelasi sederhana yang dihasilkan memang cukup besar, namun nilai korelasi parsialnya hanya 0,075. Korelasi parsial tersebut dikontrol oleh variabel kekuatan otot tungkai, power lengan dan power tungkai. Jika kita 
cermati secara mendalam, nilai korelasi antara variabel kekuatan otot lengan dengan power lengan mempunyai hubungan yang lebih kuat, yaitu sebear 0,747 namun masih dalam batas kolinearitas. Dari hal tersebut dapat disimpulkan bahwa variabel kekuatan otot lengan mempunyai hubungan yang kuat terhadap power lengan daripada hubungan terhadap prestasi renang gaya crawl 25 meter.

Nilai korelasi antara kekuatan otot tungkai dengan prestasi renang gaya crawl 25 meter yaitu 0,205. Berdasarkan pengujian hipotesis hubungan keduanya tidak signifikan. Nilai korelasi parsial yang dihasilkan yaitu 0,060. Nilai korelasi antara variabel kekuatan otot tungkai dengan ketiga variabel bebas lainnya mempunyai hubungan yang lebih kuat, meskipun hubungannya tidak sebesar hubungan pada kekuatan otot lengan. Maka dapat disimpulkan bahwa variabel kekuatan otot tungkai lebih mempunyai hubungan yang kuat terhadap power tungkai dari pada hubungan terhadap prestasi renang gaya crawl 25 meter.

Nilai korelasi antara power lengan dengan prestasi renang gaya crawl 25 meter paling kuat, yaitu 0,766 . Nilai korelasi parsial yang dihasilkan yaitu 0,606 . Dalam renang gaya crawl 25 meter, power lengan dibutuhkan saat melakukan gerakan mendorong dari depan perut sampai samping badan. Apabila seorang perenang mempunyai power lengan yang kuat, maka akan menghasilkan dorongan yang kuat ke depan, sehingga laju renang gaya crawlnya pun akan lebih cepat.

Nilai korelasi antara power tungkai dengan prestasi renang gaya crawl 25 meter yaitu 0,309. Berdasarkan pengujian hipotesis hubungan keduanya tidak signifikan. Nilai korelasi parsial yang dihasilkan yaitu -0,148. Nilai korelasi parsialnya bernilai negative yang berarti bahwa semakin besar power tungkai seseorang akan semakin lambat renang gaya crawl 25 meter.

Nilai korelasi antara kekuatan otot lengan, kekuatan otot tungkai, power lengan dan power tungkai dengan prestasi renang gaya crawl 25 meter yaitu 0,773. Berdasarkan pengujian hipotesis hubungan dari keempat variabel bebas secara bersama-sama terhadap prestasi renang gaya crawl 25 meter tidak signifikan. Hal ini dikarenakan nilai korelasi parsial dari variabel kekuatan otot legan, kekuatan otot tungkai, dan power tungkai sangat kecil. Dalam renang gaya crawl 25 meter, gerakan yang sangat penting adalah menarik, mendorong dan relaksasi. Ketika gerakan menarik, kekuatan otot lengan sangat diperlukan, dan pada saat mendorong power lengan sangat dibutuhkan karena membutuhkan hentakan yang besar agar dapat melaju dengan cepat. Gerakan kaki pada renang gaya crawl hanyalah seperti gerakan orang berjalan di darat dengan stabil. Hal ini berfungsi untuk menjaga keseimbangan posisi tubuh saja, sehingga wajar jika kekuatan otot tungkai dan power tungkai tidak mempunyai hubungan yang signifikan terhadap prestasi renang gaya crawl 25 meter.

\section{SIMPULAN}

Dari hasil penelitian bisa disimpulkan bahwa ada hubungan yang signifikan antara kekuatan otot lengan dengan prestasi renang gaya crawl 25 meter, tidak ada hubungan yang signifikan antara kekuatan otot tungkai dengan prestasi renang gaya crawl 25 meter, ada hubungan yang signifikan power lengan dengan prestasi renang gaya crawl 25 meter, tidak ada hubungan yang signifikan antara power tungkai dengan prestasi renang gaya crawl 25 meter. Secara keseluruhan tidak ada hubungan yang signifikan antara kekuatan otot lengan, kekuatan otot tungkai, power lengan dan power tungkai terhadap prestasi renang gaya $\mathrm{crawl}$ 25 meter.

\section{DAFTAR PUSTAKA}

Baja, F. R., \& Rismayanthi, C. (2019). Hubungan Tingkat Pengetahuan Diet Dan Aktivitas Fisik Terhadap Status Gizi Pada Siswa Sekolah Menengah Atas. MEDIKORA, 18(1), 16. https://doi.org/10.21831/medikora.v18i1.29189 
Evenetus, Y., Mulyana, R. B., \& Ma'mun, A. (2019). Pengaruh Program Latihan terhadap Peningkatan Kekuatan, Power, Daya Tahan Lengan dan Performa Renang 50 Meter Gaya Bebas. Jurnal Penelitian Pendidikan, 19(3), 445-455. https://doi.org/10.17509/jpp.v19i3.22337

Falaahudin, A., \& Sugiyanto, F. (2013). Evaluasi Program Pembinaan Renang Di Klub Tirta Serayu, Tcs, Bumi Pala, Dezender, Spectrum Di Provinsi Jawa Tengah. Jurnal Keolahragaan, 1(1), 13-25. https://doi.org/10.21831/jk.v1i1.2342

Firdausi, D. K. A. (2018). Peningkatan Hasil Belajar Renang Gaya Bebas. JUARA : Jurnal Olahraga, 3(2), 11-18. https://doi.org/10.33222/juara.v3i1.216

Muliarta, I. W. (2015). Pengaruh latihan interval anaerob dan power otot tungkai terhadap kecepatan renang gaya front crawl 50 meter. JST (Jurnal Sains Dan Teknologi), 4(1), 30-39. https://doi.org/10.23887/jst-undiksha.v4i1.4930

Oktadinata, A., Mardian, R., \& Maryadi, W. (2017). Analisis Keterampilan Renang Gaya Bebas Mahasiswa Putri Mata Kuliah Renang 1 FIK-UNJA. Journal Physical Education, Health and Recreation, 1(2), 1-12. https://doi.org/10.24114/pjkr.v1i2.7562

Palar, C. M., Wongkar, D., \& Ticoalu, S. H. R. (2015). Manfaat latihan olahraga aerobik terhadap kebugaran fisik manusia. Jurnal E-Biomedik, 3(1). https://doi.org/10.35790/ebm.3.1.2015.7127

Paramita, D. A., Sinrang, A. W., \& Santoso, A. (2020). Korelasi antara program latihan dengan fungsi paru dan prestasi pada atlet renang usia dewasa muda. Jurnal Pendidikan Jasmani, Olahragm Dan Kesehatan, 3(2), 201-212.

Prasetyo, Y. (2015). Kesadaran Masyarakat Berolahraga untuk Peningkatan Kesehatan dan Pembangunan Nasional. Medikora, 11(2).

Putra, \& Witarsyah. (2019). Pengaruh Latihan Daya tahan Kekuatan Otot Lengan dan Otot Tungkai Terhadap Kecepatan Renang Gaya Dada 50 Meter. Jurnal Pendidikan Dan Olahraga, 2(1), 51-56.

Rahima, Ahmad Atiq, W. Y. (2013). Keterampilan Gaya Bebas (Crawl) Dalam Olaharaga Renang Pada Mahasiswa Penjaskesrek Untan. Journal, 1(1), 1-11.

Rismayanthi, C. (2015). Konsumsi protein untukpeningkatan prestasi. MEDIKORA, 11(2). https://doi.org/10.21831/medikora.v11i2.4763

Rizkiyansyah, A., \& Mulyana, B. (2019). Pengaruh Media Papan Luncur dan Pull Buoy Pola Metode Drill terhadap Hasil Belajar Teknik Dasar Renang Gaya Bebas. Jurnal Kepelatihan Olahraga, 11(2), 112-123. https://doi.org/10.17509/jko-upi.v11i2.20311

Rohman, U. (2019). Penerapan Metode Latihan Interval dalam Meningkatkan Kecepatan Renang Gaya Bebas 50 Meter. Jurnal Ilmiah SPIRIT, 19(1), 59-67.

Setiawan, A., Jauhari, M., \& Setiakarnawijaya, Y. (2017). Tingkat Pemahaman Orang Tua 
Ardhika Falaahudin, Dody Tri Iwandana, Wildan Alfia Nugroho, Cerika Rismayanthi

Atlet Renang Kelompok Umur Empat (K.U IV) tentang Gizi di Klub Renang Indonesia Star Aquatic Jakarta Timur. JURNAL SEGAR, 3(2), 111-118. https://doi.org/10.21009/segar.0302.05

Sukmawati, D., \& Hartoto, S. (2015). Penerapan Pemebelajaran Renang Gaya Bebas Terhadap Hasil Belajar Renang Gaya Bebas. Jurnal Pendidikan Olahraga Dan Kesehatan, 3(2), 366-370.

Sungkowo, Kaswarganti Rahayu, K. S. B. (2015). Pengaruh Latihan Interval dan Kapasitas Vital Paru terhadap Kecepatan Renang 50 Meter Gaya Crawl. Media Ilmu Keolahragaan Indonesia, 5(2), 24-29. https://doi.org/10.15294/miki.v5i2.7882

Surahman, F. (2016). Pengaruh Metode Repetisi dan Metode Interval Intensif Terhadap Kecepatan Renang Gaya Bebas 50 Meter (Studi Eksperimen Pada Atlet Klub Profi Swimming Kota Padang). Curricula, 2(2), 31-40. https://doi.org/10.22216/jcc.v2i2.216

Susanto, E. (2015). Manfaat olahraga renang bagi lanjut usia. MEDIKORA, 1. https://doi.org/10.21831/medikora.v0i1.4669

Susanto, E. (2017). Pembelajaran Renang Gaya Bebas Dengan Pendekatan Gaya Mengajar Resiprokal. Journal of Chemical Information and Modeling, 53(9), 1689-1699.

Wahyudi, U. (2015). Pembelajaran renang dengan pendekatan bermain terhadap keterampilan mengapung. Pendidikan Jasmani, 25(5), 105-113.

Wicaksono, D. S. (2017). Kontribusi Kecepatan Gerakan Tangan Dan Gerakan Kaki Terhadap Kecepatan Renang Gaya Bebas 25 Meter (Studi pada Siswa SMP Hang Tua 5 yang Mengikuti Ekstrakurikuler Renang). Jurnal Pendidikan Olahraga Dan Kesehatan, $5(3)$. 